\title{
The Performance of Agricultural Cooperative Societies under the National Programme on Food Security in Enugu State, Nigeria
}

\section{Onugu Charles Uchenna Ph.D}

Email: Chaliebee-4u@yahoo.com

\author{
Abdulahi Taiwo Olabisi B.Sc \\ Department of Cooperative Economics and Management \\ Nnamdi Azikiwe University, Awka Anambra State Nigeria \\ Email: ao.taiwo@unizik.edu.ng
}

\begin{abstract}
National programme on Food Security (NPFS) is a special programme introduced by the Federal government of Nigeria on agricultural activities in order to increase food production in the country. This study is therefore an appraisal of the performance of agricultural cooperative in the National food security programme. The study was carried out in Aniri Local Government Area of Enugu State. The specific objective of the study are to ascertain the socio-economic characteristics of farmers; identify the services available to farmers in the NPFS; determine the extent agricultural services are accessible in the NPFS, appraise the effect of using agricultural cooperative societies in the implementation of NPFS as well as examine the challenges. Data were obtained from both the ADP staff and cooperative farmers using a structured questionnaire. Simple percentage and statistical package for social sciences (SPSS version 17) was employed in analyzing the data and correlation analysis was used to pair the two variables (farmers and extension workers) and t-test was used to test the hypothesis. The study revealed that agricultural cooperative societies are effective means of accessing agricultural services under NPFS. The study also revealed that both farmers and ADP extension workers encountered some challenges in their bid to achieve the goal of the programme. The study therefore recommends that there should be proper publicity and awareness on NPFS programme, adequate fund should be made available for the success of the programme and the youth should be encouraged to embrace agriculture as a means of employment.
\end{abstract}

Keywords: Cooperative, Agriculture, Agricultural Cooperative, Food Security, Agricultural Development. 


\section{Introduction}

Today, there is a growing advocacy for achieving sustainable food security in Nigeria and a lot of effort has been directed at finding appropriate structure for organizing millions of small scale farmers towards achieving food security. Agricultural cooperative society has been touted as the appropriate vehicle for harnessing and polling the resources of millions of small holder farmer producers together to enjoy the benefit of large scale production. Although the activities of the National Programme for Food Security (NPFS \} which is anchored by the Agricultural Development Programme (ADP) of states in Nigeria is a community-based participatory approach using contact farmers in the target areas, but that has not been able to reverse the upward trend in the price of food stuffs in our markets today. Cooperative according to Omotesho (2008) is one of the most effective vehicle for efficient mobilization of production resources and accelerated rural development. The importance arises from the fact that the small-scale individual capacity of the peasants production, can not cope with technological and capital demands of modernized agriculture. Even though the family farm may be considered efficient within the static framework of its motive of enterprise-self-sufficiency, the dynamic demands of modern times are such that such a framework has to be subjected to drastic structural changes. And this the peasant should be educated such that he knows that his interest is being fostered (Okolocha, 1993).

The agricultural cooperatives have been there over the years to play this role of drastic structural change in agriculture towards achieving food security and also the socio-economic upliftment of the farmers. Uchendu (1998) noted that the original impetus for the organization of cooperatives in Nigeria came from agriculture, or more precisely, from the marketing of cash coops for export. Since then cooperative development has taken different forms and dimension. According to FMRD (2001), emphasis in cooperative development is now on multipurpose agricultural cooperative for food production and marketing. He noted that, ninety-six percent of cooperative societies in this country are designed basically to serve the needs of agriculture. Even the four percent which constitute non-agricultural cooperative societies have great relevance for agriculture and use agricultural 
product and bye-products. In summary, it does appear that the government has committed itself to the realization of food security in the country. However, as to the appropriateness and gains of these efforts, Oyido (1997) has noted that, virtually all the programmes and policies were beautiful and fulfilling but they could not achieve their set objectives because of over dependence on the 'Black Gold' which has become the major foreign exchange earner on which the economy depends. Indeed government efforts over the years could not guarantee adequate food and fibre for the citizenry, thus; the country has increased its dependence on food imports. For example wheat imports from the United states in 2007 alone was $\$ 2.2$ billion. Government's efforts can at best be described as failure since not less than $65 \%$ of Nigerians are food insecure (Muhammed (2008).

This precarious situation has necessitated the National Programme on Food Security (NPFS); a special programme introduced by the Federal Government of Nigeria on agricultural activities to increase food production in the country. Its activities are being carried out in the thirty-six states of the country, plus the Federal Capital Territory (FCT) Abuja. In Enugu State, NPFS activities are mainly on agricultural activities, namely crop farming, livestock, fishery and processing of agricultural products. The component structure of NPFS in Enugu State is mainly the State Agricultural Development Programme (ADP) staff on one hand and the beneficial community-based farmers.

\section{Statement of the Problem}

Food production in Nigeria is not keeping pace with population growth. This has resulted in the upward trend in the price of food stuff. Thus, creating a wide gap between the demand and supply of food. According to Ajayi (2008), the resulting effect of this imbalance between demand for and supply of food is malnutrition, poverty and deteriorating living conditions. Hence, the need to improve Nigeria agriculture. Over the years Nigeria has been having a teething problem feeding it teeming population all year round and this is partly because it has not been able to adopt an improved farming technique. According to Idachaba (1995), the Nigeria agriculture depends overwhelmingly on low productivity resources, land of progressively declining fertility, unskilled farm 
labour, the hoe matchet, low yielding seed variety and planting material. Low yielding agricultural and traditional farming practices, poor yield and high cost of food prices.

High production cost are compounded by high processing and transportation cost on account of the primitive state of rural infrastructures especially rural roads, heavy post harvest losses both in storage and transportation reduce available marketable and marketed surpluses and result in high food prices, especially in the urban areas (ldachaba, 1995). Limited finance and poverty of the Nigeria farmers have also been identified as factors militating against food production. As noted by Obinyan (2000), their holdings are small, most often less than two hectares and are characterized by low productivity. This leads to low income and low capital investment. Consequently, one of the possible ways of redressing these constraints is to mobilize the desperate small holder farmer for economy of scale and agricultural cooperative is a veritable platform for this exercise. The challenge in this work is to study the agricultural development programme of Enugu State and find out how the agricultural cooperative have being performing under it, in terms of achieving national food security.

The issues here are whether the agricultural services available to farmers under the NPFS are made available to them? Also, are agricultural cooperative societies really involved in the implementation of the series? Equally, what challenges face the executives of NPFS in Enugu State and what can be done to strengthen the programme?

\section{Objective of the Study}

The broad objective of this study is to appraise the performance of agricultural cooperatives societies in the National programme for Food Security with Enugu State as a case. Specifically the objectives are to:

i. Ascertain the socio economic characteristics' of the farmers and extension service providers involved in the programme.

ii. Identify the agricultural services available to farmers in the NPFS

iii. Determine the extent agricultural services obtainable in the NPFS are extended to Agricultural cooperative society in the state. 
iv. Ascertain the role of agricultural co-operative societies in making available agricultural services obtained in the NPFS to rural farmers.

v. Appraise the effect of using agricultural co-operative societies in accessing services of the NPFS.

vi. Examine the challenges of using agricultural co-operative societies in implementing the NPFS.

vii. Make deductions based on the above findings on ways of strengthening the use of agricultural cooperative societies in the NPFS in the Enugu state

\section{Hypotheses for the study}

Three hypotheses were set for the study and they are:

Ho: : The opinion of farmers and extension workers differ significantly on the accessibility of services provided by NPFS.

Ho$_{2}$ : The opinion of farmers and extension workers differ significantly on the involvement of agricultural cooperative societies in the implementation of NPFS services.

Ho $:$ The opinion of both farmers and extension workers differ significantly on how effective agricultural cooperative societies are in making NPFS services available.

\section{Literature Review}

\section{Meaning of Food Security}

The importance of food to individuals and households cannot be overemphasized. According to Abudullahi (2002), food is not only a basic need; it also provides the physiological foundation upon which other considerations and human activities are structured. He noted that for us in Nigeria, food security is both a national objective and a challenge. Food security is not simply having sufficient and adequate quantities of our various staple foodstuffs but it also entails access to the entire citizenry to these food items at affordable prices. It further means that not only must we engage in mass food production, but also we need to ensure that most Nigeria have sufficient purchasing power to acquire food items that guarantee good feeding and nutrition. According to Adisa (1992), "food security can be defined simply as access by all people at all times to enough food for an active and healthy life. 
Accordingly, Eboh (1995) described it thus: food security simply refers to the ability of individuals and households (especially the rural and urban poor) to meet staple food needs all year round".

Continuing, Eboh (1995), states that the above description is essentially intra-generational food security as opposed to inter-generational food security, which refers to the ability of future generations to meet their food needs, on season and off season. Carter (1989) has this to say about food security; "food security may be defined as the ability of food-deficit regions or countries, or households within these countries, to meet target levels of consumption on a yearly basis". They noted that what constitutes target consumption levels and the ability to maintain consumption is being referred to as two central issued of a country's food policy.

All the above definitions have stressed that food security is of supreme importance in improving the nutritional status of many millions of people who suffer from persistent hunger and under-nutrition and many others who are at the risk of facing the same situation. They have also touched some important components of the concept of food security. For instance, Carter (1989) and Adisa (1992) talked of food sufficiency, food adequacy and food accessibility. World Bank (1986), Kennedy and Hadded, (1992), noted that food security is access by all peoples at all times to enough food for an active, healthy and productive life. Word Bank (2006) observed that there are four key components or concepts implicit in the above definitions of food security, viz; food availability, stability of food supply, food access and food utilization. These concepts will further be analysed. Akinyele (2009) supports the view of Word Bank (2006) by noting that food availability, stability of supplies and food access are related determinants of food security.

\section{Food Availability, Stability of Food Supplies, Food Access and Food Utilization}

According to Akinnyele (2009), at the household level, food security implies an adequate access to food over time. This is possible when there is adequate food availability to the household, and an adequate income capacity for the purpose of the available food. Stability of food implies that the food availability is not affected by any shocks or risks 
affecting food production at all times. Food access according to him has three components:

- Physical access to food,

- Economic access to food, and

- Sustainable access to food.

Availability of food, stability of food supplies and access are therefore three essential determinants of food security. Physical access implies food availability or food supply to the household, as there might be food available at the national level which however may not trickle down to the household level. According to Ekundayo (2008), Food availability means that enough food should be available to meet consumption needs. This relates to the need to produce enough food to the extent that it gets into the market for sale to consumers at affordable prices. Stability of food supplies is the ability to ensure that food consumption will not fall below the consumption requirements at all times including in difficult months, seasons or years. Food access concerns the ability of people to have economic access to the food needed for healthy and productive life. Economic access depends on income; households that can generate sufficient income to buy the food needed can have an entitlement to that food. Food utilization refers to the ability of the individual members of the household to utilize food consumed for growth, nutrition and health. Food security incorporates questions of production, storage and supply as well as access to supply Lawal and Oke, (2008). It entails not only food availability through domestic consumption, storage and/or trade, but also, and perhaps more importantly, food access through home production, purchase in the market, or food transfer (Abudullahi (2002).

\section{Challenges and Prospects of Food Security In Nigeria}

Ukeje (2008) has noted that although appreciable real output growth rates have been achieved in the agricultural sector in the last five years, a significant break-through in productivity to effectively guarantee domestic self-sufficiency is still constrained by a number of challenges. These challenges are the inadequacies in the supply and delivery of farm inputs; shortages of working capital; low rate of technology adoption; diseases and pests infestations; poor post-harvest processing and storage technology; environmental hazards; and land constraint. 


\section{Inadequate supply of Farm Inputs}

The unavailability of major farm inputs critical for agricultural production (fertilisers, seeds, agro-chemicals, machineries, etc) at the appropriate time and at the right prices has remained a source of worry and frustration. Government efforts to develop efficient and effective input procurement and distribution systems that will ensure timely delivery of adequate quantity and quality of farm inputs to farmers have not been successful. Despite the large sums of money that had been spent on procurement and subsidisation of farm inputs, the problems of availability, accessibility, stability and sustainability still remain. The adoption of many promising improved packages of technology has been compromised by the unavailability of the complimentary farm inputs. The persistence of the problem has been attributed largely to the issue of subsidy and its administration, as evidenced in the procurement and distribution of fertiliser by the Government. This is an activity the private sector is believed to be better equipped technically to handle. The price regulating mechanism of a commodity whose supply could not match the demand at the stipulated prices create rent seeking and there are more unintended beneficiaries, who are the fertiliser contractors, haulers, etc. The result of all these actions is that many farmers do not have access to adequate supply of fertilisers with the consequence that Nigerian farmers have not been able to use fertilizers at the desired level to optimize their benefits to increase food production. Farm input play very critical role in the modernisation of small holder agriculture and this issue need to be properly addressed.

\section{Inadequate Working Capital}

Small scale farmers do not have adequate capital to expand their scale of operations and/ or take advantage of profitable packages of technology to boost productivity. The bulk of capital injection by this category of farmers comes from owner's equity and informal credit sources. The price and exchange rate reforms that accompanied the Structural Adjustment Programme of 1986 have increased the costs of production and significantly increased the working capital needs of agricultural activities. 
The long and cumbersome bureaucratic processes have prevented the flow of official credit through the government established credit schemes to the farmers. This problem is more pronounced for the female headed household who has nothing to offer as collateral. If objective of food security is to be attained, the issues of women empowerment should be taken seriously. There is also the need for effective support for the formation and growth of farmers cooperatives to assist in accessing credit, using the group for the mobilization and guarantee.

\section{Inadequate Capital Expenditure}

The volume of capital allocation to agriculture and the quality spending over the years have been low and poor. The share of agriculture in total capital expenditure which averaged about 2.5 per cent need to be increased. The adequacy of capital and effective implementation of projects will ensure the effective provision of infrastructure and encourage research into crop production.

\section{Low Rate of Technology Adoption}

The reduction and outright elimination of subsidies on all agricultural machinery like tractors, harvesters, harrowers and planters following deregulation has reduced the use of machines in agricultural activities. The postharvest technology available in Nigeria is poor and grossly inadequate to cope with vibrant, market-oriented food production efforts of Nigeria's small holders. Apart from the damage which the crops are exposed to in the field as a result of pests and disease attacks, a considerable proportion of the harvest is lost due to poor processing and storage technique. Crop losses have been estimated to be as high as 20 per cent of harvest in some cases.

\section{Poor Extension Services}

The twin problem of inadequate extension services and the low morale of the available extension staff need to be addressed. More emphasis should be placed on having well trained extensionists and consideration should be given to female extension workers to address the problem of gender access to new innovations. Effort should be made as a matter of priority to ensure that the salaries and allowances of this important group of workers are paid regularly. 


\section{Environmental Hazards}

The problems of drought/ desertification, as well as, soil erosion have remained very serious for Nigerian agriculture. These problems often manifest in the forms of soil degradation and deforestation. While some of these changes are caused by natural forces, they could also be caused by the direct result of over-grazing, over- cultivation, bush burning and deforestation associated with increased population and poor conservation practices. Attempts to solve the problems have been through nation-wide tree planting campaigns in the past and encouraging people to switch to the use of fuel efficient facilities, like stove and gas cookers. Unfortunately, the prices of stoves and gas cookers have risen sharply, thereby making them out of the reach of most rural dwellers. The increase in petroleum products prices has also resulted in farmers resorting to the bush for their fuel. Furthermore, the afforestation programme has been slowed down due to inadequate funding by government, increase in cost of planting materials, inadequate water and manpower to implement the afforestation programme. Also, proper conservation practices have not been learned by the rural dwellers.

\section{Post Harvest Losses}

The problem of inadequate storage facilities has compounded the problem of food security. It is estimated that about $15-20$ per cent of the crops produced are lost before they can be consumed. This situation is made worse by the dearth of agro-processing industries in the country. It also has a discouraging effect on the farmers as the struggle to sell most of their crops immediately after harvest results in cut throat competition and lower prices.

\section{Low Level of Education}

The low level of education of small scale farmers, especially women who form the bulk of the agricultural labour force has remained a major constraint to the adoption of modem farming techniques and the ability to access other inputs necessary for increased productivity in the sector. 


\section{Communal/Religious Crisis}

The frequent communal/religious crisis in some region of the country is a major constraint to food security in Nigeria. The crises occur either during planting, weeding or harvesting period and with the flight of farmers from the areas irrespective of the stage of farming, food security Is threatened as most, if not all the crops are lost.

In spite of the above negative factors, Ukeje (2008) is optimistic that Nigeria can still overcome her food problems. The reasons for his optimism are centred on the following factors:

- $\quad$ Abundant land resources for the production of crops, livestock and forestry products,

- A large domestic and international market for agricultural commodities.

- $\quad$ The liberalization of trade will help farmers to get better prices for their exports.

However, private sector marketing agencies are needed to help ensure the quality of export commodities.

- The ban on imports of livestock products, maize, wheat and vegetable oils should help domestic producers.

- The subsisting government policy to reserve $30 \%$ of the elective post for women will go a long way in enhancing gender empowerment for the rural women.

However, the achievement of increased agricultural production and food security will require a comprehensive strategy to reduce some important constraints that has been earlier described. As much as the above opinion of Ukeje is valid, there is also the need to address the more important issue of political will. Omotesho (2008) has warned that ... "Achieving food security and reducing poverty is not an issue of right policies or programme rather that of a strong political will and absolute patriotism on the part of the people at the helm of affairs, who are to implement the policies and execute the programmes.

\section{The African Food Crises and the Global Response}

Africa is the poorest part of the world economy. The total GNP of the 45 countries in the sub-Saharan Africa in 1985 was one third of the 
GNP of the State of California and slightly less than the total GNP of Spain (a relatively poor European country) with a population of 40 million (World bank 1987). Sixteen of the 20 poorest nations in the world are African (Nur, 1989). Between 60 and 80 percent of the population of African countries are engaged in agriculture and agriculturally related occupations. In most parts of Africa, agriculture is typically subsistent. The traditional tools, seeds, livestock and methods are still in use. Consequently, the size of farm is typically small, since it is a factor of technology at his disposal. Agriculture depends largely on the natural vicissitudes of weather. Therefore any slight variation in the precarious balance between man and nature, from the optimal conditions of production spells doom to crops and livestock, and this threatens the very existence of rural households, the community and the nation. At independence in the 1960, most African countries have monocrop economies depending on only one major crop for export to earn foreign exchange. However, most of them were producing enough to feed themselves, and even some were known to be net exporters of food. Nigeria, at independence was largest exporter of palm oil and second largest exporter of groundnut. Congo was the largest exporter of bananas etc. Africa natural endowment in arable land notwithstanding it has turned to a food deficit continent. It has been shown that 19. African countries were importing 8 million tons of food annually and about 100 million Africans do not get enough food (Nur, 1989).

Further to the above, Carter (1989) has asserted that most Sub-Saharan African countries are food insecure. Clearly, with a food import bill of $\$ 19$ billion and agricultural export of $\$ 14$ billion in 2003, the continent appears to have reversed from being a key exporter of agricultural commodities into being a net importer. It also has the highest percentage of undernourished people and has shown the least progress on reducing the prevalence of undernourishment in the last 30 years. Chronic food insecurity now affects some $28 \%$ of the population-that is, nearly 200 million people who are suffering from malnutrition. Acute food insecurity in 2003 is affecting 38 million people in Africa who are facing the outright risk of famine, with 24,000 dying from hunger daily. Famines are the most visible and extreme manifestation of acute food 
insecurity. Of the 39 countries worldwide that faced food emergencies at the beginning of 2003, 25 are found in Africa (Ugwunedo, 2008).

Asuaobi (2000) also acknowledged the precarious nature of African food situation when it noted that. Over the ten year period of 1990-92 to 2000-02, AV Commission analysis of available information shows that, there was a slight decrease in the percentage of the population estimated to be under- nourished (29 to 27 percent); an increase in the number of persons "hungry" from 176 to 210 million due to population increasing more rapidly than the percentages of hunger reduction; quite striking differences in reducing hunger across the sub-regions with the North already at low rates and the Southern sub-region having made the most significant progress; country and sub-regional performance in hungerreduction has been strongly affected by conflict situations, with conflict causing substantially more disruption than natural disasters; and, Sixtythree percent of Africa's people live in countries where the percentage of the population suffering from under-nutrition has declined from 36 to 29 percent. The culmination of the above is that African continent is now the continent receiving most food aid, with some 30 million people requiring emergency food aid in one year. Sixty per cent of the World Food Programme (WFP)'s work now takes place in Africa. Aid officials have estimated that their budget for Africa is $\$ 1.4$ billion for feeding those who will face starvation in the coming months if they do not receive considerable food assistance. It is of great concern that only $\$ 700$ million had been raised in Africa. Aid officials have estimated that their budget for Africa is $\$ 1.4$ billion for feeding those who will face starvation in the coming months if they do not receive considerable food assistance. It is of great concern that only $\$ 700$ million had been raised by the end of 2002 (Ugwunedo 2008). The hunger crisis spans the entire continent and has grown particularly acute in the wake of two major, simultaneous regional emergencies in the past year. Southern Africa is facing the most severe crisis in which, according to Food and Agricultural Organisation (FAO) latest figures, 16.7 million people are in need of emergency assistance to survive until the next harvest in April 2003. This has been a crisis that has emerged in slow motion, the extent of which has become apparent only gradually although the first warning bells were rung as early as mid-2000. During the course of 
2002, Malawi, Zimbabwe, Zambia and Lesotho each declared a national disaster and appealed to the international community for help. The most dangerous situation is developing in Zimbabwe, a country which until recently was a surplus food producer. Developments in Swaziland and Mozambique are also of great concern. Serious food shortages are also looming in several countries in the Horn of Africa where at least 17.5 million are without sufficient food. The needs are most urgent in Eritrea and in Ethiopia where it is feared that this crisis could be as bad as the 1984 famine. Millions more also face starvation in the long-running disasters in war-afflicted Sudan and Angola, as well as the Great Lakes region and the Sahel of Western Africa (FAO, 2002).

The continuing response from the international community to the food crisis has not stabilized food security and food shortages are likely to increase. The current emergency conditions are worsening. This crisis is not going to disappear even with improved climatic conditions. These countries will need ongoing assistance for many years to come in agriculture and health.

\section{Agricultural Cooperatives: Their Nature And Role In Food Security}

Cooperatives are economic enterprises founded by and belong entirely to the members. These enterprises are created in order to render the best possible service at the lowest possible cost to their members. Cooperative stands over two legs, in order to be solid and sustained (Akinwumi, 1989):

- The equal ownership of members of their cooperative. Members pay with their money, be it by cash payments or by loans undertaken by the cooperative, to create the fixed assets of the cooperative. Therefore, the cooperative belongs to them entirely, equally, and members own equal shares. These are the Property Shares. In most cooperatives in Africa, and in other parts of the world, this notion doesn't exists, and the cooperatives belong to members on an indivisible basis namely, belonging to everyone commonly and belonging practically to no one. In my view this is one of the major 
reasons to the declining of many cooperatives in so many places.

- The cooperative is rendering to members the best possible service at the lowest possible cost. This means that cooperatives are working not to generate profits or surplus to enable the head of the cooperative, at the AGM, to show to members that he was successful in creating this wealth. This wealth came from members pockets when applying a policy of very expensive price of participation on members. Members have created their cooperatives when they believed it will rendered them a service, or enabling to purchase a commodity in so low price, they couldn't afford when alone. There can be many variations to the agricultural cooperative model each playing a critical function in fulfilling its members' needs. Supply cooperatives, for example, make various products available to its members, while marketing cooperatives act as a marketing body for farmers to sell their products. Some cooperatives combine both these activities while others provide additional services such as custom harvesting of crops. The cooperative structure and its function are limited only by the needs of its members and the commonality of their goals.

The FAO (1997) was emphatic that cooperatives could make the needed impact in food security efforts through mobilizing farmers, women and finance and in agricultural marketing. FAO however warns that cooperatives may not be able to play a significant role until they have fully adjusted to market conditions. Many agricultural cooperatives are now in a period of transition from government-controlled markets, often allowing cooperatives to have a monopoly for certain regulated crops, to open market conditions. Not having been exposed to competition before, the cooperatives are now restructuring themselves and adjusting to the new business environment. Some cooperatives will not be able to adapt and will therefore be eliminated by the competition. There are cases where cooperatives have lost the better part of their market share. On the other hand, there are many cooperative organizations that have managed to revitalize themselves by providing better services, improving their business performance and implementing organizational 
changes and mergers. This ongoing transformation will result in fewer but more efficient cooperatives, and it is not unlikely that new structures will emerge that are better adapted to market oriented economies.

However, in order to emerge successfully as competitive business organizations on the new market, cooperatives will need an enabling environment. Such an environment will have to comprise a conducive cooperative policy and law as well as a framework to regulate the open market. This would not only put cooperatives on an equal footing with other market agents, but it would also enable them to contribute more to sustainable agricultural production and food security. Furthermore, if governments and cooperatives are equally willing to enter into a partnership in which the cooperatives are given a true participatory role, the inherent qualities of cooperatives, member-owned and membergoverned organizations can be brought into full play for the cause of food security.

\section{Methodology}

The study adopted a field survey approach and the methodology used followed the under listed sub headings.

\section{Area of Study}

The area of study is Aninri Local Government Area (LGA); one of the 17 LGA's in Enugu State. It has boundaries as thus: by the North; Awgu LGA; by the South, Ivo LGA of Ebonyi State; by the West Nkanu LGA; and by the East Oji River.

Aninri, has a population of 133, 723 people (NPC, 2006). It has a flat, swampy and very rich soil with its inhabitants mainly smallholder farmers.

\section{Population of the study}

The population of the study are59 members of agricultural cooperative societies operating National programme on food security and 19 ADP staff that took part in extension services to the cooperative societies. 
Sampling size and sample procedure

Since the population of the ADP staff is relatively small, we use the whole population as the sample size which is 19 , also yaro yameni was applied to get the sample size of the cooperative members to 51 .

Data collection: a structure questionnaire targeted at the members of agricultural cooperative and ADP extension workers were used for data collection.

Data Analysis: The study made use of both descriptive and inferential statistics in data analysis. Statistical tools used include simple and multiple response percentages (\%), Likert scale measure, correlation, and t-test for analyzing the data from the respondents.

\section{Test for Hypotheses}

The three hypothesis; $\mathrm{Ho}_{1}, \mathrm{Ho}_{2}$ and $\mathrm{Ho}_{3}$, set for the study were analyzed through correlation analysis and t-test statistics. Stated below are explanation and result of the tests of the hypotheses.

\section{Hypothesis 1}

Data for testing the above hypothesis is deduced from table 3, which dwelt on responses of rural farmers as well as extension service providers on the accessibility of NPFS services.

$\mathbf{H}_{\mathbf{0 1}}$ : The opinion of farmers and extension workers differ significantly on the accessibility of services provided by NPFS.

$\mathrm{H}_{\mathrm{A} 1}$ : The opinion of farmers and extension workers do not differ significantly on the accessibility of services provided by NPFS.

Accessibility paired sample statistics

\begin{tabular}{|l|l|l|l|l|}
\hline & Mean & $\mathbf{N}$ & $\begin{array}{l}\text { Std. } \\
\text { Deviation }\end{array}$ & $\begin{array}{l}\text { Std. Error } \\
\text { Mean }\end{array}$ \\
\hline $\begin{array}{l}\text { Pair 1 farmer \& } \\
\text { ext worker }\end{array}$ & .59256 & 18 & .339750 & .080080 \\
.68861 & 18 & .325492 & .076719 \\
\hline
\end{tabular}


Paired samples correlations

\begin{tabular}{|l|l|l|l|}
\hline & $\mathbf{N}$ & Correlation & Sig \\
\hline $\begin{array}{l}\text { Pair 1 farmer \& ext } \\
\text { worker }\end{array}$ & 18 & -.162 & .520 \\
\hline
\end{tabular}

\begin{tabular}{|l|l|l|l|}
\hline & \multicolumn{3}{|l|}{ Paired differences } \\
\hline Pair farmer and ext worker & Mean & $\begin{array}{l}\text { St. } \\
\text { Deviation }\end{array}$ & $\begin{array}{l}\text { Std. Error } \\
\text { mean }\end{array}$ \\
\hline $\begin{array}{l}\text { Pair 1 farmer and ext } \\
\text { worker }\end{array}$ & 0.096056 & 0.507202 & 0.119549 \\
\hline
\end{tabular}

\begin{tabular}{|l|l|l|l|l|l|}
\hline & \multicolumn{2}{|l|}{ Paired differences } & \multicolumn{2}{|l|}{} \\
\hline & $\begin{array}{l}\text { 95\% confidence interval } \\
\text { of the differences }\end{array}$ & \multicolumn{3}{|l|}{} \\
\hline & Lower & Upper & t & df & $\begin{array}{l}\text { Sig (2- } \\
\text { tailed) }\end{array}$ \\
\hline $\begin{array}{l}\text { Paired 1 farmer } \\
\text { and ext workers }\end{array}$ & 0.348281 & 0.156170 & 0.803 & 17 & 0.433 \\
\hline
\end{tabular}

Sources: SPSS (version 17)

Decision: Since the table value is less than the calculated value $(\mathrm{P}<0.05)$ we reject the null hypothesis $(\mathrm{Ho})$ and accept the alternative hypothesis $\left(\mathrm{H}_{\mathrm{A}} 1\right)$. Therefore the opinion of the farmers and the extension workers does not differ significantly on the accessibility of the NPFS services to farmer cooperative.

\section{Hypothesis 2}

Data used for this particular hypothesis was generated from table 4 which shows responses on how involved the agricultural cooperative societies are in the implementation of NPFS services.

$\mathbf{H}_{\mathbf{0 2}}$ : The opinion of farmers and the extension workers differ significantly on the involvement of farmers cooperative society in the implementation of NPFS services. 
$\mathbf{H}_{\mathrm{A} 2}$ : The opinion of farmers and the extension workers do not differ significantly on the involvement of agricultural cooperative society in the implementation of NPFS services.

Cooperative involvement Paired sample test

\begin{tabular}{|l|l|l|l|l|}
\hline & Mean & N & $\begin{array}{l}\text { Std. } \\
\text { Deviation }\end{array}$ & Std. Error Mean \\
\hline $\begin{array}{l}\text { Pair 1 farmer \& } \\
\text { ext worker }\end{array}$ & 0.15279 & 14 & 0.118567 & 0.031688 \\
0.23800 & 14 & 0.172199 & 0.046022 \\
\hline
\end{tabular}

Paired samples correlations

\begin{tabular}{|l|l|l|l|}
\hline & N & Correlation & Sig \\
\hline Pair 1 farmer \& ext worker & 14 & 0.257 & 0.375 \\
\hline
\end{tabular}

\begin{tabular}{|l|l|l|l|}
\hline & \multicolumn{3}{|l|}{ Paired differences } \\
\hline Pair farmer and ext worker & Mean & $\begin{array}{l}\text { St. } \\
\text { Deviation }\end{array}$ & $\begin{array}{l}\text { Std. Error } \\
\text { mean }\end{array}$ \\
\hline Pair 1 farmer and worker & 0.085214 & 0.232805 & 0.06220 \\
\hline
\end{tabular}

\begin{tabular}{|l|l|l|l|l|l|}
\hline & $\begin{array}{l}\text { Paired } \\
\text { differences }\end{array}$ & \multicolumn{3}{|l|}{} \\
\hline & $\begin{array}{l}\text { 95\% confidence } \\
\text { interval of the } \\
\text { differences }\end{array}$ & & \multicolumn{3}{|l|}{} \\
\hline & Lower & Upper & T & df & $\begin{array}{l}\text { Sig } \\
(\mathbf{2}- \\
\text { tailed) }\end{array}$ \\
\hline $\begin{array}{l}\text { Paired } \\
\text { farmer-ext } \\
\text { workers }\end{array}$ & 0.219632 & 0.049203 & 1.370 & 13 & 0.194 \\
\hline
\end{tabular}

Sources: SPSS (version 17)

Decision: Since the table value is less than the calculated value $(\mathrm{P}<0.05)$ we reject the null hypothesis $\left(\mathrm{H}_{\mathrm{o}} 2\right)$ and accept the alternative hypothesis $\left(\mathrm{H}_{\mathrm{A}} 2\right)$. Therefore, the opinion of the farmers and the extension workers do not differ significantly on the involvement of the 
agricultural cooperative society in the implementation of NPFS services.

\section{Hypothesis 3}

The data that was used to test this hypothesis was acquired from table 5 which shows the responses on how effective in using agricultural cooperative society for accessing agricultural services of NPFS.

$\mathbf{H}_{\mathbf{0 3}}$ : The opinion of farmers and extension workers differ significantly on how effective agricultural cooperative societies are in making NPFS services available.

$\mathbf{H}_{\mathrm{A3}}$ : The opinion of both farmers and extension workers do not differ significantly on how effective agricultural cooperative societies are in making NPFS services available.

Effective of farmer cooperative Paired samples Test

\begin{tabular}{|l|l|l|l|l|}
\hline & Mean & N & Std. Deviation & $\begin{array}{l}\text { Std. Error } \\
\text { Mean }\end{array}$ \\
\hline $\begin{array}{l}\text { Pair 1 farmer \& } \\
\text { ext worker }\end{array}$ & 4.7500 & 4 & 4.64579 & 2.32289 \\
12.7500 & 4 & 15.26161 & 7.63080 \\
\hline
\end{tabular}

Paired samples correlations

\begin{tabular}{|l|l|l|l|}
\hline & N & Correlation & Sig \\
\hline $\begin{array}{l}\text { Pair 1 farmer \& ext } \\
\text { worker }\end{array}$ & 4 & 0.953 & 0.047 \\
\hline
\end{tabular}

\begin{tabular}{|l|l|l|l|}
\hline & \multicolumn{3}{|l|}{ Paired differences } \\
\hline Pair farmer and ext worker & Mean & $\begin{array}{l}\text { St. } \\
\text { Deviation }\end{array}$ & $\begin{array}{l}\text { Std. Error } \\
\text { mean }\end{array}$ \\
\hline Pair 1 farmer and worker & 8.00 & 10.92398 & 5.46199 \\
\hline
\end{tabular}




\begin{tabular}{|l|l|l|l|l|l|}
\hline & \multicolumn{2}{|l|}{ Paired differences } & \multicolumn{3}{l|}{} \\
\hline & \multicolumn{2}{|l|}{$\begin{array}{l}\text { 95\% confidence interval } \\
\text { of the differences }\end{array}$} & \multicolumn{3}{|l|}{} \\
\hline & Lower & Upper & t & df & Sig (2-tailed) \\
\hline $\begin{array}{l}\text { Paired 1 } \\
\text { farmer and } \\
\text { ext workers }\end{array}$ & 25.38249 & 9.38249 & 1.465 & 3 & 0.239 \\
\hline
\end{tabular}

Sources: SPSS (version 17)

Decision: Since the table value is less than the calculated value $(\mathrm{P}<0.05)$ we reject the null hypothesis $\left(\mathrm{H}_{\mathrm{o}} 3\right)$ and accept the alternative hypothesis $\left(\mathrm{H}_{\mathrm{A}} 3\right)$. Therefore, the opinion of the farmers and the extension workers do not differ significantly on how effective agricultural cooperative societies are in making NPFS services available.

\section{Result and Discussions}

\section{Socio-economic characteristics of respondents}

The socioeconomic characteristics of the farmers and the ADP extension workers are presented in table 1 . The result shows that majority of the farmers $(94.1 \%)$ and extension workers $(94.7 \%)$ are married. Most (64.7\%) of the farmers, belonged to the age range of 31 40 years, whereas majority $(63.2 \%)$ were in the age range of $41-50$ years. The result also indicate that there were more $(60.8 \%)$ female farmers in the project than males, while the result was opposite for ADP extension farmers, where fourteen $(73.7 \%)$ are males. Their educational background showed that most $(72.5 \%)$ has first school leaving certificate (FSLC), while sixteen $(84.2 \%)$ of the extension workers has HND/B.Sc. as the most and highest educational background. The table also showed that for the farmers, that majority (56.8\%) has 11-15 years farming experience, whereas for the ADP extension workers, most $(42.1 \%)$ has $16-20$ years field experience.

\section{Services rendered through NPFS to rural farmers}

Table 2 is a multiple responses of services rendered through the NPFS as identified by the providers (Extension Workers) and end-users cooperative farmers). The prominent services include: sensitization on 
NPFS; HIV/AIDS prevention; training on nutrition and health; disbursement of loan; livestock production and animal health; diversification of crop production; agro-processing; and linking of farmers to better markets. Over $60 \%$ of the farmers and ADP extension workers affirmed the provision of the aforementioned NPFS services.

\section{Accessibility of NPFS services to farmers}

Table 3 displays a four point linkert-scale measure; very accessible (4); accessible (3); somewhat accessible (2); and not accessible (1); of how accessible NPFS services are available to the farmers. The result shows that over $50 \%$ of the respondents (farmers and extension workers) indicated that services such as sensitizations of NPFS services, formation of groups training of groups, training on nutrition/health mobilization of savings and disbursement of loans; provision of market information and linking farmers to better markets; agro-processing; HIV/AIDS prevention; enhancement of crop production; diversification of crop production; seed multiplication; and; livestock production and animal health were accessible to the farmers. To further assert this findings, $\mathrm{H}_{\mathrm{O}} 1$ as indicated earlier in the data analysis, sought to find out whether a significant different exist in the opinion of the extension providers and end-users (farmers)) on the accessibility of NPFS services. With the values of t-cal (0.803) and confidence level, we conclude that their opinion does not differ. This therefore strengthens the fact that NPFS services were accessible to farmers.

\section{Involvement of farmers cooperative society in implementation of NPFS services}

Table 4 is a four-point linkert-scale measure: very involved (4); involved (3); somewhat involved (2); not involved (1); of how involved the farmers cooperative societies are in the implementation of NPFS services. The result shows that over $50 \%$ of both the farmer cooperative members and their extension agents agreed that farmers cooperative societies were involved in the implementation of such services as: sensitization on NPFS services; formation of groups; training of cooperative groups; HIV/AIDS preventive; training on nutrition and health; mobilization of savings; disbursement of loans; provision of market information; linkage of farmers to better markets, enhancement 
of crop production; diversification of crop production; deed multiplication; livestock production and animal health; and; agro processing. To further assert this findings, $\mathrm{H}_{\mathrm{O}} 2$ as indicated earlier in the data analysis sought to find out whether the opinion of the extension service providers (EA's) differ significantly from that of the end users (farmers) on how involved the cooperative societies are in the implementation of NPFS services. The result showed a t-cal (1.370) and t-tab (0.194), at 0.05 confidence level. This implies that their opinion does not differ and hence strengthens the fact that the agricultural cooperative societies were involved in the implementation of NPFS services.

\section{Effectiveness of using agricultural cooperative society in accessing agricultural services under the NPFS programme}

Table 5 reveals the opinion of the respondents on the effectiveness of using agricultural cooperative societies in accessing agricultural services under the NPFS. Based on the result majority $(52.8 \%)$ of the farmers and over half (53\%) of the extension workers indicated they were very effective. In furtherance of asserting the result, $\mathrm{H}_{\mathrm{O}} 3$ divert on determining whether the opinion of the extension workers differ significantly from that of their subjects (farmers). The result as earlier indicated in the data analysis, with a t-cal (1.465) and t-tab (0.239) at 0.05 confidence level, indicated otherwise. The result therefore justifies the potency of using agricultural cooperative societies in accessing agricultural services to farmers under the NPFS.

\section{Challenges of implementing the NPFS programme}

Table 6 reveals the multiple responses of the extension service providers as well as cooperative farmer members on challenges they encounter in implementing the NPFS programme. Sixteen challenges were listed out of which nine (9) were mostly noted. They include insufficient fund, recognized by $78 \%$ (farmers) and $58 \%$ (extension workers); mismanagement of fund (58\%), notion of loan as national cake $(71 \%)$, and dishonesty among farmers (63\%) recognized by extension workers as major challenges. The others are the high cost of input noted by $28(54 \%)$ of the farmers; late disbursement of loan identified by $61 \%$ of the farmers as well as $58 \%$ of their extension 
service providers. The rest are group disintegration recognized by $67 \%$ of the farmers and $74 \%$ of extension workers as constraints; and weak enterprise management noted by $57 \%$ of the farmers and $58 \%$ of the extension service providers.

\section{Conclusions and Recommendations}

National Programme on Food Security was introduced to boost food production to feed the teeming population adequately and on a sustained bases. The programme guides rural farmers to form groups as cooperative societies to enable them pull their resources and effectively access NPFS service, with less difficulty. The programme aims at employment generation, attraction of government attention to rural farmers, infrastructure in rural areas, reduction in rural-urban migration, while making the nation to be food secured. The findings of the study reveal that:

i. The personal characteristics of both the rural farmers and NPFS extension providers were ideal to facilitate their active participation in the programme.

ii. Prominent services rendered to rural farmers through the NPFS programme include; community sensitization and mobilization for the programme; formation and training of cooperative groups; HIV/AIDS prevention and training on health/nutrition; diversification of crop production; market information and linking of farmers to better markets; value addition through agroprocessing.

iii. Most of the aforementioned NPFS services were found accessible to the rural farmers.

iv. There was clear proving of the involvement of the agricultural cooperative societies in the implementation of NPFS services.

v. There was also a proven effectiveness of using the agricultural cooperative societies in facilitating the accessibility of agricultural services to rural farmers under the NPFS programme.

vi. That, despite the aforementioned successes, that challenges notable among which are insufficient fund for the farmers, wrong notion of loans by farmers as national cake, dishonesty among farmers, late disbursement of loan, weak enterprise management and group disintegration exists. 


\section{The study finally makes the following recommendations:}

i) There should be adequate and prompt disbursement of approval fund.

ii) There should be sufficient re-orientation of the farmers to mitigate their wrong notion on loan as national cake.

iii) The programme should strengthen capacity on group leadership, cohesion and ethics to address issue of group disintegration and dishonesty among members.

iv) There should also be emphases on facilitating the farmers management skills to reduce business failure.

v) Efforts should be made to ensure that the groups are not just hurriedly formed as cooperatives. They should be rather properly formed, registered and supervised by the government cooperative authorities. This if done will enthrone sustainability.

vi) The extension service providers must be motivated and encouraged to sustain proper monitoring and supervision of farmers and their enterprise to for stale diversion of loan and failure.

\section{References}

Abdullahi, H. (2002), "Putting Globalization to work for the poor: sustainable food security for all by 2020." Proceedings of an International Conference Organized by IFPRI, washing ton, D.C.

Ajayi, M. (2008). "Implications of Macro-Economic policy for National Food Security in Nigeria". Paper Presented at the 2008 Annual Conference of the Development Finance Department of Central Bank of Nigeria (CBN), held at Orchid Hotel, Asaba, Delta State, from $15^{\text {th }}-18^{\text {th }}$ October.

Akinwumi, J.A. (1989). "Cooperatives: The Answer to Nigeria's Producer Consumer Dilemma" Faculty series 2. Faculty of Agriculture, University of Nigeria Nsukka. 
Akinyele E. (2009). Nigeria Food consumption and Nutrition Survey, International Institute for Tropical Agriculture (IITA) Ibadan.

Asuobi, C. (2008) "Household Food security as assessed by Dietary intake and anthropometry of presho children in cassava producing areas of Nigeria". In Nwosu et al (ed) Agricultural transformation in Nigeria Novelty Industrial Enterprise Ltd, Owerri.

Carter, J. (1989), "The challenges of Agricultural Production and Food security In Africa" In Proceeding of the International conference on Food security in Africa, organized by Africa Leadership forum, held at Ota Farm, Nigeria. July $27^{\text {th }}-30^{\text {th }}$.

Eboh E.C. (2005) Development: The Theory and Implication for rural areas. Enugu Auto century publishing company.

Ekundayo, Femi (2008). "The Role of Financial Institutions In Addressing National Food Security" Paper presented at the 2008 Annual Conference of the Central Bank of Nigeria $(\mathrm{CBN})$, held at Orchid Hotel, Asaba, Delta State, from $15^{\text {th }}-$ $18^{\text {th }}$ October.

FAO (2002): “Agriculture Towards 2015/30". Technical Interview Reports, Food and Agricultural Organization (FAO) Rome.

FAO (1997). "Comprehensive Africa Agricultural Development Programme". Food and Agricultural Organization (FAO) Corporate Document Repository. Accessed of www.pap.org.

FMARD (2001). Reports on Special Programme on Food Security: Project UTF/NIR/047/MR. Federal Ministry of Agriculture and Rural Development (FMARD).

Idachaba, F.S. (1995) Agriculture in Nigeria: Identifying opportunities for increased commercidization and US AID/Nigeria. 
Kenedy, J. \& Hadded, L. (1992). "Agricultural Research and Poverty Reduction", Food, Agriculture and the Environment Discuss paper, No. 34, IFFRI Washington DC.

Lawal, R.M. and Oke, J.O. (2008). "Repositioning the Strategic Food Reserve in Addressing the Global Food Crises and National Development". Paper presented at the 2008 Annual Conference of the Development Finance Department of Central Bank of Nigeria (CBN), held at Orchid Hotel, Asaba, Delta State, from $15^{\text {th }}-8^{\text {th }}$, October.

Muhammed, L.A. (2008), “An Analysis of Food Insecurity situation in Rural Households in Kwara state, Nigeria". An unpublished Ph.D. Thesis, Department of Agricultural Economics and Farm Management, University of Ilorin, Kwara state, Nigeria.

Nur, I.M. (1989). "The Food crises In Africa: In The challenge of Agricultural Production and food security in Africa". Proceeding of the International conference on Food security in Africa.

Obiyan, E.(2000). “The private sector and Agricultural Transformation. UAC seeds zone" in Nwosu et al (ed), Agricultural transformation in Nigeria. Owerri Novelty Industrial Enterprises Ltd.

Okolocha, C.F. (1993). "Rural Employment Mechanization and Peasant production: An Analysis of Ekpoma Rice Industry \& Perspective on Food Security In Nigeria". In Nigerian Rural sociological Association.

Omotesho, Olubunmi Abayomi (2008). "Global Food Crises and National Food Security: Strategic obtions for Nigeria". Paper presented at the 2008 Annual conference of the Development Finance Department of Central Bank of Nigeria (CBN), held at Orchid Hotel, Asaba, Delta State. $15^{\text {th- }} 8^{\text {th }}$, October. 
Oyido, I. (1997) "Poverty Alleviation Agenda for Food security in Integrated Production in Nigeria: Strategies and Mechanisms for Food Security". In Federal Ministry of Agriculture \& Natural Resources (FANR) Bulletin. No. 114. Lagos.

Uchendu (1998); Fundamentals of Cooperation business enterprise, published by Rejoint Communication Ltd, Uwani Enugu.

Ukeje, M.F. (2008) Agricultural Development Issues, It's sustainability and food security in Nigeria. Paper presented at the 2008 Annual conference of the Development Finance Department of Central Bank of Nigeria (CBN), held at Orchid Hotel, Asaba, Delta State. $15^{\text {th- }} 8^{\text {th }}$, October.

Ugwunedo C. (2008). "Food crises: The African challenge" Called from Http://www.nigeria.com/dcforum/deforumid/795.Html Accessed on Sept. $7^{\text {th }} 2008$.

World Bank (1986), Poverty and Hunger: Issue and options for food security in Developing countries, Washington D.C. 